\title{
EXHAUST EMISSIONS EVALUATION OF COLOMBIAN COMMERCIAL DIESEL FUELS
}

\author{
Jaime Torres*1, Arcesio Bello ${ }^{1}$, Jose Sarmiento ${ }^{1}$, Jacek Rostkowski ${ }^{2}$ and Jeremy Brady ${ }^{2}$ \\ 1 Ecopetrol S.A. - Instituto Colombiano del Petróleo, A.A. 4185 Bucaramanga, Santander, Colombia \\ ${ }^{2}$ Emissions Research and Measurement Division, Environment Canada, Ottawa, Ontario,Canada \\ e-mail: jatorres@ecopetrol.com.co
}

(Received 29 May 2003; Accepted 4 November 2003)

\begin{abstract}
$\mathrm{E}$ copetrol, based on the results obtained in the study "The Effect of Diesel Properties on the Emissions of Particulate Matter" (Bello et al., 2000), reformulated the diesel fuel distributed in Bogotá, becoming it lighter and with a lower sulfur content. In order to evaluate the environmental benefits that the reformulation of diesel fuel generate in Bogotá, Instituto Colombiano del Petróledo (ICP), with the assistance of Emissions Research and Measurement Division (ERMD) from Environment Canada, arranged a research project to determine the changes in $\mathrm{CO}, \mathrm{THC}, \mathrm{NO}_{\mathrm{x}}, \mathrm{CO}_{2}$ and Particulate Matter emissions. The research program was developed in two steps. First one, developed in Bogotá, involved a fleet test with 15 public service buses that normally operate in Bogota's Savannah, using a portable emissions sampling technology developed for ERMD (DOES2) and following a representative transient driving cycle. Second step, carried out in ERMD's Heavy-Duty Engine Emissions Laboratory in Ottawa, tested a 1995 caterpillar 3406E 324,5 kW (435 HP) diesel truck engine on the same samples of Colombian diesel fuels used in the fleet tests performed in Bogotá, baselining the tests with a Canadian Commercial Low Sulfur Diesel Fuel.

The two commercial Colombian diesel fuels used had the following properties: High Sulfur Diesel (HSD), with $3000 \mathrm{ppm}(0,3 \mathrm{wt} \%)$ of sulfur and a Final Boiling Point (FBP) of $633 \mathrm{~K}$ and the new reformulated diesel fuel, with 1000 ppm $(0,1 \mathrm{wt} \%)$ of sulfur and FBP of $613 \mathrm{~K}$, which is currently been distributed in Bogotá. Fleet test show small reduction on $\mathrm{CO}, \mathrm{THC}$ and TPM, and small increments on $\mathrm{CO}_{2}$ and $\mathrm{NO}_{x}$, but with not statistically significant results, while engine testing shows an strong reduction of $40,8 \%$ in TPM when you use the new reformulated diesel fuel $(0,1 \mathrm{wt} \%$ of sulfur) instead of high sulfur diesel.
\end{abstract}

Keywords: diesel emissions, particulate matter, sulfur content.

* To whom correspondence may be addressed 
copetrol, basado en los resultados obtenidos en el estudio "Efecto de las Propiedades del Diesel sobre la Emisiones de Material Particulado" (Bello et al., 2000), reformuló el combustible diesel que se distribuye en Bogotá, haciéndolo más liviano y con un contenido de azufre más bajo. Con el objeto de evaluar los beneficios medioambientales que la reformulación del combustible diesel genera en Bogotá, el Instituto Colombiano del Petróleo (ICP), con la asistencia de la División de Investigación y Medición de Emisiones (ERMD) del Ministerio del Medio Ambiente de Canadá, organizaron un proyecto de investigación para determinar los cambios en las emisiones de $\mathrm{CO}, \mathrm{THC}, \mathrm{NO}_{x}, \mathrm{CO}_{2}$ y Material Particulado. El programa de investigación fue desarrollado en dos etapas. La primera, desarrollada en Bogotá, involucró una prueba de flota con 15 buses de servicio público que normalmente operan en la Sabana de Bogotá, utilizando una tecnología portátil para el muestreo de emisiones desarrollada por ERMD (DOES2) y siguiendo un ciclo de manejo transciente representativo. En la segunda fase, desarrollada en el Laboratorio de Emisiones de Motores de Trabajo Pesado de ERMD en Ottawa, se probó un motor Caterpillar 3406E diesel de un camión modelo 1995 de 324,5 kW (435 HP) con las mismas muestras de combustibles diesel colombianos usados en las pruebas de flota desarrolladas en Bogotá, utilizando como línea base para las pruebas un combustible diesel comercial canadiense de bajo azufre.

Los dos combustible diesel comerciales colombianos utilizados tenían las siguientes propiedades: Diesel de Alto Azufre (DAA), con 3000 ppm (0,3\% en peso) de azufre y un Punto Final de Ebullición (PFE) de $633 \mathrm{~K}$ y el nuevo combustible diesel reformulado, con 1000 ppm (0,1\% en peso) de azufre y PFE de $613 \mathrm{~K}$, el cual está siendo corrientemente distribuido en Bogotá. Las pruebas de flota mostraron pequeñas reducciones de $\mathrm{CO}$, THC y TPM, y pequeños incrementos de $\mathrm{CO}_{2}$ y $\mathrm{NO}_{x}$, pero con resultados estadísticamente no significativos, mientras que la evaluación en el motor muestra una fuerte reducción de 40,8\% en TPM cuando se usa el nuevo combustible diesel reformulado $(0,1 \%$ en peso de azufre) en vez del diesel de alto azufre

Palabras claves: emisiones diesel, material particulado, contenido de azufre. 


\section{INTRODUCTION}

The objectives of changing the specifications and formulation of diesel fuel distributed in Bogotá, were to reduce the particulate matter and sulfur dioxide $\left(\mathrm{SO}_{2}\right)$ emissions, in order to improve Bogota's air quality, and to supply a fuel with enough quality to satisfy the requirements for the new mass transportation media (transmilenio) (Bello et al., 2000). To evaluate the real environmental impact that Bogotás diesel reformulation had on diesel emissions, Ecopetrol- Instituto Colombiano del Petróleo (ICP) and Emissions Research and Measurement Division (ERMD) Environment Canada designed a project that included tests with a fleet of 15 diesel vehicles, which were operating in the older public transportation system in Bogotá's area and after that, and using the same samples of fuels used during the fleet test, ERMD developed an exhaust emissions evaluation program in its Heavy-Duty Engine Emissions Laboratory in Ottawa running a 1995 caterpillar $3406 \mathrm{E} 324,5 \mathrm{~kW}$ (435 HP) diesel truck engine. This project was carried out through a collaborative agreement signed between both Canadian and Colombian government entities.

The ERMD is a division of Environment Canada, the Federal Canadian environmental authority. This government emissions research laboratory has a mandate to investigate the emissions from mobile sources and to evaluate industry-related devices and alternative fuels that are designed to benefit the environment (e.g. fuel consumption improvements, exhaust emissions reductions, etc). Ecopetrol is the national oil corporation in Colombia and the Instituto Colombiano del Petróleo (ICP) is its Research and Development Center.

\section{Background on diesel engine exhaust}

The overall chemical reaction of combustion is,

$$
\text { Fuel }+ \text { Oxidant } \longrightarrow \text { Products }+ \text { Heat Release (1) }
$$

For the compression ignition / internal combustion of diesel engines, the fuel used is a liquid hydrocarbon (approx. $\mathrm{C}_{14,4} \mathrm{H}_{24,9}$ ) and the oxidant comes from ambient air (approx. 21\% oxygen and 79\% nitrogen). The heat released from the reaction is converted into usable power by its expansion of the product gases that, in turn, push the engine piston. Ideally, the above reaction
(1), which comprises hundreds of intermediate chain reaction steps, becomes:

$$
\begin{aligned}
& \text { Diesel Fuel }\left(\mathrm{C}_{14,4} \mathrm{H}_{24,9}\right)+ \\
& \text { Air }\left(21 \% \mathrm{O}_{2}+79 \% \mathrm{~N}_{2}\right) \longrightarrow \\
& \quad \text { Carbon Dioxide }+ \text { Water Vapor } \\
& \quad+\text { Nitrogen }+ \text { Mechanical Energy }
\end{aligned}
$$

This ideal situation describes complete combustion where all of the carbon in the fuel is reacted to form carbon dioxide $\left(\mathrm{CO}_{2}\right)$ and all of the hydrogen in the fuel reacts to form water $\left(\mathrm{H}_{2} \mathrm{O}\right)$. The nitrogen gas $\left(\mathrm{N}_{2}\right)$ comes from the air and is unaffected by the process.

In reality, combustion in diesel engines is never complete. This shortcoming occurs when the chain reactions of combustion are arrested at some intermediate step. In the region surrounding the flame, reaction interruptions occur due to an insufficient provision of oxygen (rich mixture) or due to excessive heat loss (quenching). The first product of incomplete combustion to appear is usually carbon monoxide $(\mathrm{CO})$ as its reaction to $\mathrm{CO}_{2}$ is slower than rates of the other reactions in the chain. A worsening of conditions may result in the appearance of various hydrocarbons from the broken reaction chains. In the hottest areas of the combustion chamber where there is an excessive fuel presence (rich zone), solid carbon particles are produced which then enter the exhaust in the form of soot. Besides the $\mathrm{CO}$ and the unburned hydrocarbons of incomplete combustion, oxides of nitrogen ( $\mathrm{NO}$ and $\mathrm{NO}_{2}$ - generally referred to as $\mathrm{NO}_{\mathrm{X}}$ ) are a considerable product. They are formed by the reaction between atmospheric $\mathrm{N}_{2}$ and $\mathrm{O}_{2}$ at high temperatures and will remain in the products as the exhaust gases cool coming out of the exhaust manifold.

The overall reaction that best describes the combustion in a compression ignition (CI) of a diesel engine can then be presented as:

$$
\begin{aligned}
& \text { Diesel Fuel + Air } \stackrel{\text { compression }}{\longrightarrow} \\
& \text { Carbon Dioxide + Carbon Monoxide + Water } \\
& + \text { Oxygen + Nitrogen + Oxides of Nitrogen } \\
& \quad+\text { Hydrocarbons + Particulates } \\
& \quad+\text { Mechanical Energy }
\end{aligned}
$$


Or in simpler notation

$$
\begin{aligned}
& \text { Diesel Fuel }+ \text { Air } \stackrel{\text { compression }}{\longrightarrow} \\
& \text {. } \mathrm{CO}_{2}+\mathrm{CO}+\mathrm{H}_{2} \mathrm{O}+\mathrm{O}_{2}+\mathrm{N}_{2}+\mathrm{NO}_{X}+\mathrm{THC} \\
& + \text { P.O.M. + Mechanical Energy }
\end{aligned}
$$

With regards to the reactant quantities, diesel fuel is injected at an average rate of approx. 1 part fuel: 18 parts air into the combustion chamber. This ratio takes into account that diesel engines operate in a significant lean regime from stoichiometric (i.e. $\varphi \leq$ $0,8)$. Figure 1 shows the mass balance for a typical diesel engine combustion.

\section{The environmental effects of diesel exhaust}

Among diesel engine exhaust emissions, $\mathrm{NO}_{\mathrm{x}}$ and particulate matter have been of greatest concern to environmental regulatory bodies (Walsh, 1993). It should be noted that $\mathrm{CO}_{2}$ is, in fact, a favorable product of combustion. As shown in reaction [2], carbon dioxide's formation indicates the completeness of combustion. However, it should also be mentioned that $\mathrm{CO}_{2}$ has been shown to contribute to the greenhouse effect and global warming.

The rationale for reducing the undesirable pollutant emissions from internal combustion engines is appreciated when some of the biological effects are considered.

\section{Carbon monoxide}

$\mathrm{CO}$ is the most dangerous pollutant that internalcombustion engines emit. It is poisonous to all forms of life. Inhalation of this gas removes oxygen from people's blood and prolonged exposure can be fatal.

\section{Oxides of nitrogen}

Once dispersed into the atmosphere, $\mathrm{NO}_{\mathrm{x}}$ will decompose with certain hydrocarbon compounds (V.O.C.'s - see below) to form smog, or it will combine with atmospheric moisture and create acid rain. This byproduct of combustion is also known to be poisonous to the environment. Concentrations found in exhaust gases will cause immediate irritation in one's mucous membranes upon inhalation.

\section{Unburned hydrocarbons}

The environmental impact of gaseous varieties of HC's is apparent in the formation of photochemical smog. Specific hydrocarbons, referred to as Volatile Organic Compounds (V.O.C.'s), are those compounds known to be reactive. The most hazardous component of this smog is ground-level ozone. Human exposure to ozone can diminish lung capacity and cause other respiratory problems. Plant life has also been shown to exhibit retarded growth patterns during prolonged exposure to ozone.

\section{Particulate matter}

The fine, dark colored soot visible in the exhaust of diesel engines is known as Particulate Matter (PM). As has been found in many investigations around the world, sulfur content is the dominant fuel property affecting particulate emissions (Lange, 1991)(Cowley et al., 1993)(Den Ouden et al.,1994). This solid substance is mainly composed of ash or carbon, with heavy hydrocarbons adsorbed in it. It also contains sulfates in proportion to the fuel sulfur content. It is hazardous to all forms of life because of its carcinogenic properties.
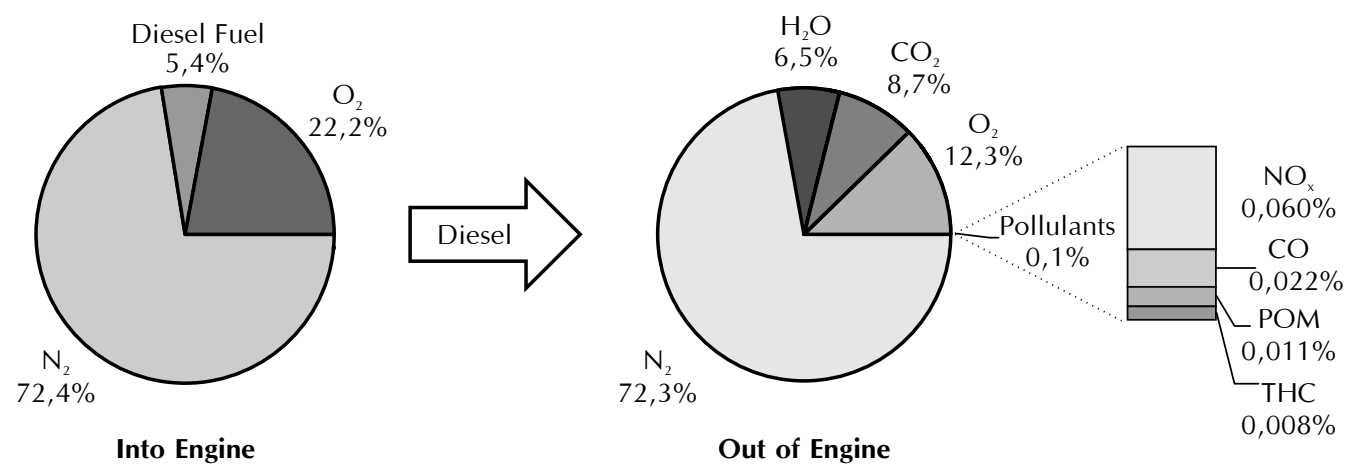

Figure 1. Typical diesel engine combustion mass balance $(\varphi \leq 0,8)$ 


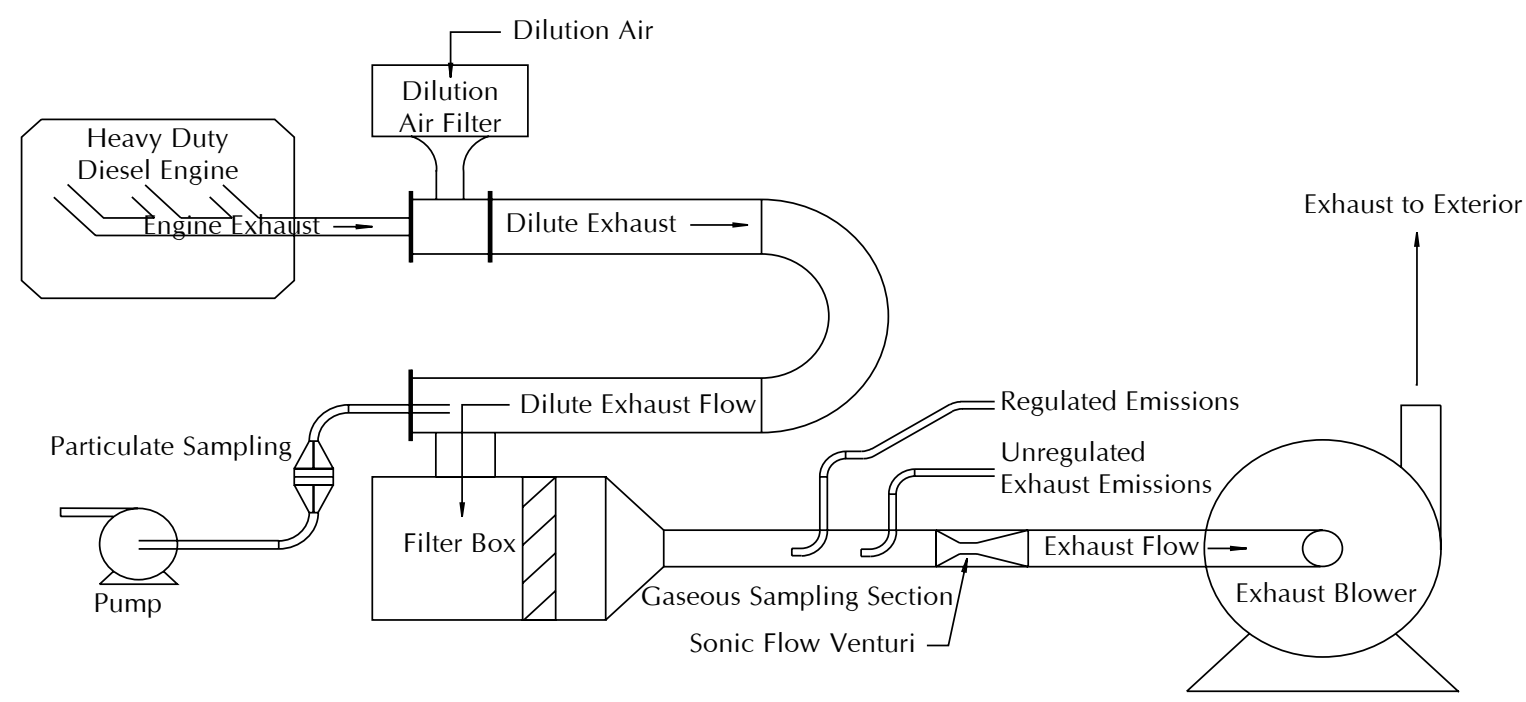

Figure 2. Constant volume sampling system for an engine test cell

\section{DESCRIPTION OF TEST PROGRAM}

\section{Testing vehicles and engine}

In all, for fleet testing, a total of 15 vehicles were used while they were fuelled with both the $3000 \mathrm{ppm}$ and $1000 \mathrm{ppm}$ sulfur diesel. In an attempt to make this sample of 15 vehicles more representative of the fleet of buses operating in Bogotá, the fleet of selected vehicles were composed of five standard full-sized vehicles (60 passengers, called bus), five medium sized vehicles (30 passengers, called buseta), and five small sized vehicles (19 passengers, called microbus). None of these vehicles had a classified engine technology for emissions control and most of them was non electronically controlled with direct injection systems, supercharged or naturally aspirated in a couple of cases (two busetas).

For testing on Heave-Duty Engine Emissions Laboratory in Ottawa, ERMD used a 1995 caterpillar 3406E with a maximum power of $324,5 \mathrm{~kW}(435 \mathrm{HP})$ at 1800 rpm and a maximum torque of $2100 \mathrm{~N}-\mathrm{m}(1550 \mathrm{lbf}-\mathrm{ft})$ at $1450 \mathrm{rpm}$. This engine has similar characteristics to the engines that transmilenio, the new Bogotá's mass transportation systems, demands to be installed in its fleet of buses (EURO II).

\section{Mobile emission sampling system (DOES2) and HD engine emissions laboratory}

The mobile emission sampling system device (DOES2), developed entirely by the ERMD, operates on many of the same principles as, and in some respects is similar in design to the constant volume sampling (CVS) systems, defined by Environment Protection Agency (EPA) in the Code of Federal Regulations No. 40 part 86. (CFR, 1995). An entire CVS system, as shown in Figure 2, is quite large and heavy (around 20' by 20 ' room and 1000 pound weight) so, using such a system during field testing would obviously not be practical, hence the reason why the portable system has been developed.

The mobile exhaust sampling system, that was used during the fleet testing, is much more portable. It measures approximately 3' long by 3' tall and about 2,5' wide. It weighs approximately $150 \mathrm{lbs}$. Its relatively small size and weight allowed it to be easily installed in the rear section of the vehicles, near the area of the exhaust system where the sample is being drawn from. The purpose of this system is to draw a properly diluted and proportioned sample from the exhaust of the vehicles during actual on-road testing. A small fraction of this sample was then drawn out of this dilution system and captured in an opaque gaseous sample bag. This 


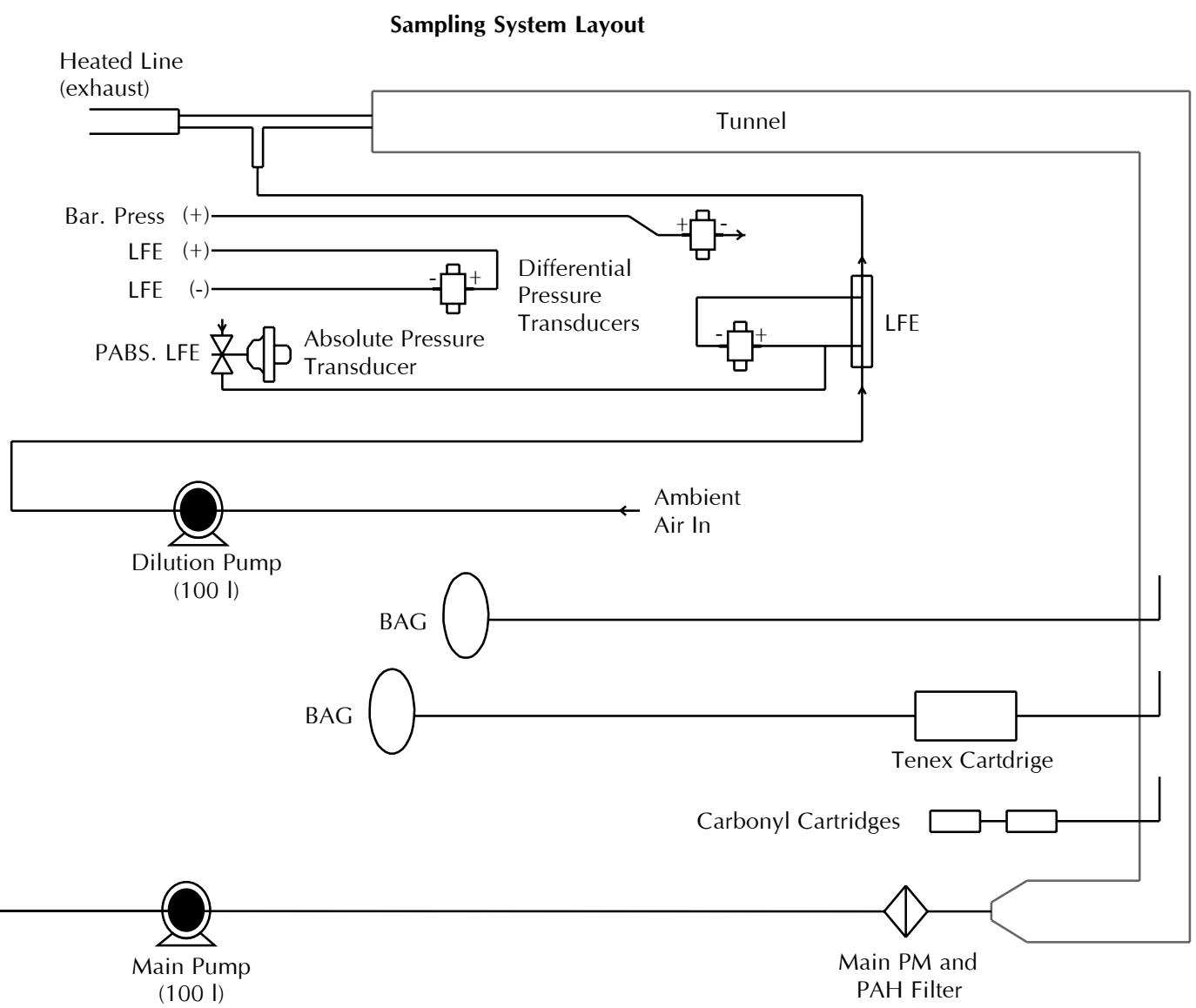

Figure 3. Mobile exhaust sampling system

arrangement allows for the measurement of the true mass of the gaseous and particulate emissions from the engine's operation. See Figure 3 for a schematic of the mobile exhaust sampling system (DOES2).

Capturing a properly diluted sample is achieved through this systems constant surveillance of the exhaust output of the vehicle being tested. As this information is monitored, exhaust emission dilution rates within the mobile sampling system change. The amount of diluted exhaust sampled out of this system and into the sample bag remains constant throughout the testing. Maintaining a properly conditioned sample is vital to this system. To achieve this a heated line is used to transport the raw exhaust sample from the probe in the exhaust pipe to the exhaust inlet of the mobile sampling system. Maintaining a heated sampling line is particularly important while measuring total hydrocarbons and oxides of nitrogen. An opaque sampling bag was used to prevent the reaction of $\mathrm{NO}_{\mathrm{x}}$ with sunlight while it was being transported from the test site to the emissions sampling bench.

The exhaust gas sampling system, for engine emission testing, used in the ERMD's HD engine emissions laboratory use a double-dilution critical flow venturi (CFV) constant volume sampler (CVS) (Figure 2). This system transferred the raw engine exhaust to a stainless steel tunnel 10 inches in diameter and 100 inches in effective length, where it is diluted with ambient air. Coupled to the dilution tunnel was a secondary dilution tunnel, which draws out a set volume of diluted exhaust and dilutes it again (double dilution), thereby conditioning the sample and enabling particulate collection in accordance with accepted test procedures. The flow rate in the main tunnel during emissions testing was a nominal $2000 \mathrm{scfm}$. 


\section{Emissions analysis apparatus}

Determination of total particulate matter during fleet testing and engine testing, was performed by gravimetry (filter weight gain). During testing, a pre-weighed 70 $\mathrm{mm}$ glass fiber filter is used to capture the total particulate matter flowing through the mobile emission sampling system (DOES2) or the particulate matter in the double diluted sample gases from the CFV-CVS installed in ERMD's HD engine emissions laboratory. Before weighing the filters, these are conditioned, placing them in a desiccator for 24 hours. After the testing is complete the filter is removed and placed in a petri dish. Subsequently, this filter is introduced again in the desiccator for 24 hours to condition it in the same way that was made before the initial weighed. Then, the filter is weighed again to obtain the final weight. The net difference between the initial and final weight of this filter indicates the mass of particulate matter sampled during testing. The microgram balance used has a precision of 10 micrograms.

For gaseous emissions during fleet testing, samples were collected in bags at the test site and brought back to a analyzer bench. It consisted of four separate analyzers, four mass flow controllers, and related pumps. Using a dedicated, specialized instrument for each component of the exhaust emissions resulted in a level of accuracy of $0,5 \%$ of the measurements. The following detection methods were used to quantify the concentrations of gaseous emissions in the bag:

Oxides of Carbon $\left(\mathrm{CO}\right.$ and $\left.\mathrm{CO}_{2}\right)$ - non-dispersive infrared detection

Total hydrocarbons (THC) - flame ionization detection

Oxides of Nitrogen $\left(\mathrm{NO}_{\mathrm{X}}\right)$ - chemiluminesence detection

For engine testing in Ottawa, a continuously-integrated system was used for determining the THC and $\mathrm{NO}_{\mathrm{x}}$ emissions during the testing. This system draws a sample of the dilute exhaust through a heated probe, heated filter, and heated sample line to the heated Flame Ionization Detector (for THC) and the heated Chemiluminescence instrument (for $\mathrm{NO}_{\mathrm{x}}$ ). The temperatures of the heated components were maintained at 191 degrees Celsius. Similarly, continuous measurements of $\mathrm{CO}$ and $\mathrm{CO}_{2}$ concentrations were taken throughout the engine duty cycle. This was performed with two separate NonDispersive Infrared (NDIR) detection analyzers.

\section{Testing Fuels}

The 3000 ppm diesel fuel, or High Sulfur Diesel (HSD), has characteristics similar from that distributed in Bogotá before February 29 of 2000 and remains being distributed in the rest of Colombian regions. Diesel fuel containing 1000 ppm of sulfur, or Low Sulfur Diesel (LSD), comply with the specifications defined for the diesel fuel that is being distributed in Bogotá since March 1 of 2000. These two diesel fuels were obtained directly in Barrancabermeja's refinery from the storage tanks of final products. Their characteristics can be seen in Table 1. For fleet testing, emissions produced for the fleet with HSD, was used as the baseline and the variations of emissions were determined based on the emissions with this fuel.

For engine testing, besides of using the two commercial diesel fuels, a commercial Canadian low sulfur diesel fuel was used for baseline testing. Fuel properties of commercial Canadian low-sulfur diesel were: sulfur content $440 \mathrm{ppm}$ and density $834 \mathrm{~kg} / \mathrm{m}^{3}$.

\section{Test cycles and plan of testing}

For fleet testing, the test program was conducted in such a way that Bogotá's urban traffic conditions were simulated as closely as possible. This simulation was desired so that test results would accurately define the comparative exhaust emissions for the $3000 \mathrm{ppm}$ and $1000 \mathrm{ppm}$ sulfur diesel while these vehicles were in operation. The second major consideration was that the tests can be as repeatable as possible, under the testing conditions that you normally have on road tests. A plot of the test time and distance vs. velocity for the test trace that was adopted is shown in Figure 4. The testing took place on a flat, three-lane highway located just north of Bogotá and in a circuit of 10 kilometers.

In order to simulate the normally charge of the vehicles while in operation, a number of sandbags were placed in the vehicles prior to testing, such that the buses contained a weight equivalent to that seen when the bus was filled to capacity with sat down passengers.

In most cases, a series of two tests were performed with each diesel fuel. In addition, one initial test series was always ran to familiarize the driver with the trace 
Table 1. Characteristics of Testing Fuels

\begin{tabular}{|c|c|c|c|}
\hline Test & Units & High Sulphur Diesel & Low Sulphur Diesel \\
\hline Density at $288,6^{\circ} \mathrm{K}$ & $\mathrm{kg} / \mathrm{m}^{3}$ & 870,8 & 854,5 \\
\hline API Gravity & ${ }^{\circ} \mathrm{API}$ & 30,9 & 34,0 \\
\hline Sulfur (\%w) & $\%$ wt & 0,324 & 0,092 \\
\hline Viscosity at $373 \mathrm{~K}$ & $\mathrm{~m}^{2} / \mathrm{s}$ & $1,54 \mathrm{E}-06$ & $1,28 \mathrm{E}-06$ \\
\hline Viscosity at $313 \mathrm{~K}$ & $\mathrm{~m}^{2} / \mathrm{s}$ & $4,51 \mathrm{E}-06$ & 3,33E-06 \\
\hline Flash point & K & 367,0 & 370,0 \\
\hline Cetane Index & Cetane & 47,0 & 49,1 \\
\hline \multicolumn{4}{|l|}{ Distillation } \\
\hline IBP & K & 499,2 & 498,9 \\
\hline 5\% Evaporated & K & 523,1 & 515,9 \\
\hline 10\% Evaporated & K & 532,0 & 520,3 \\
\hline 20\% Evaporated & K & 542,2 & 526,8 \\
\hline $30 \%$ Evaporated & K & 551,3 & 533,1 \\
\hline 40\% Evaporated & K & 559,0 & 539,3 \\
\hline 50\% Evaporated & K & 566,6 & 546,5 \\
\hline 60\% Evaporated & K & 575,3 & 555,3 \\
\hline 70\% Evaporated & K & 584,8 & 565,2 \\
\hline 80\% Evaporated & K & 595,8 & 577,8 \\
\hline 90\% Evaporated & K & 610,6 & 594,8 \\
\hline 95\% Evaporated & K & 621,3 & 607,4 \\
\hline EBP & K & 629,9 & 614,9 \\
\hline Residue & $\mathrm{ml}$ & 0,9 & 1,1 \\
\hline
\end{tabular}

that was being used. This was also an excellent mean of allowing the engine to warm-up and stabilize before the testing could commence.

The Initial test run - Baseline (3000 ppm) Fuel configuration was performed after all of the equipment was loaded onto the bus and everything was required for the testing was ready. The driver began following the trace while being coached for some of the system (DOES2) operators.

The Baseline test - Baseline (3000 ppm) Fuel configuration began after arriving at the start of the test circuit. By this time the engine and all emissions testing equipment was sufficiently warmed-up. Two series of this emissions test were performed.

The Fuel exchange - Alternative (1000 ppm) Fuel was connected to supply fuel to the engine. At the same time the return fuel was routed to a waste fuel container to prevent the 1000ppm-diesel fuel from becoming contaminated. The engine was left running for five minutes during this procedure.

The Alternative fuel test - Alternative (1000 ppm) Fuel configuration began after the vehicle had again arrived at the beginning of the test circuit, once the fuelling system of the engine was purged and all 

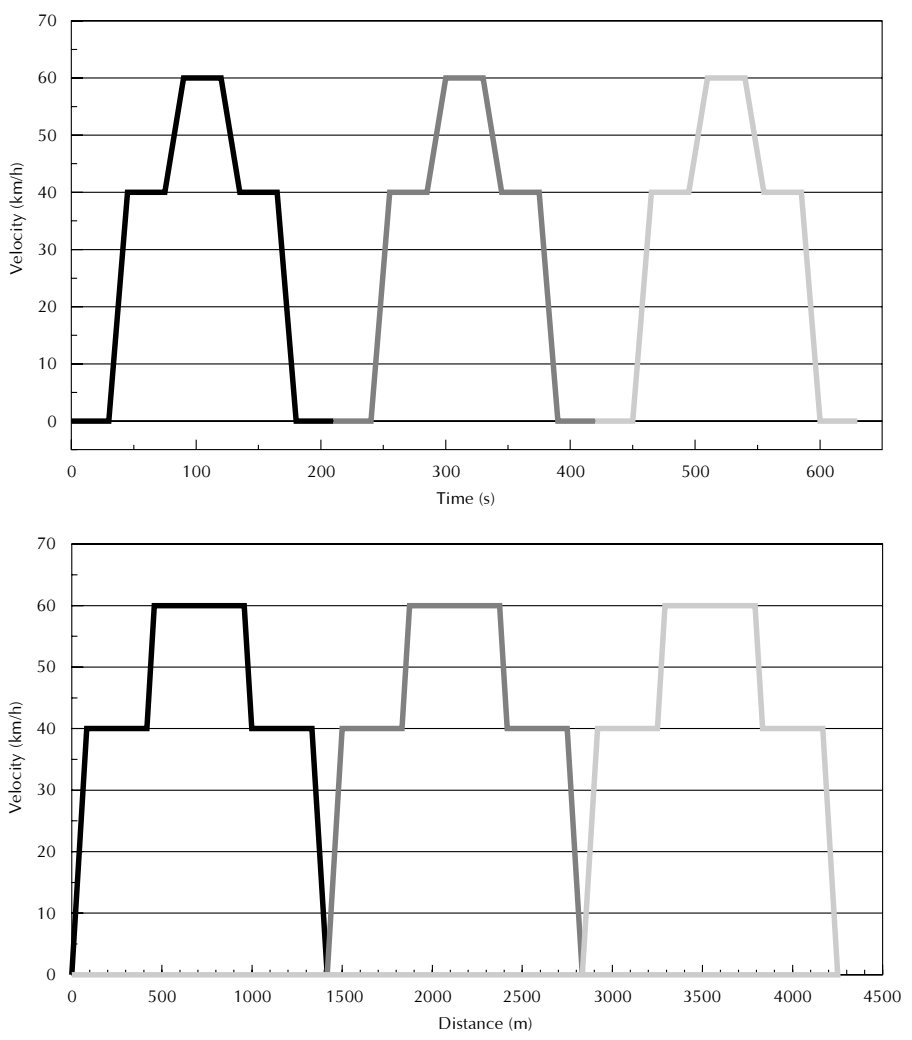

Figure 4. Plot of test time and distance versus velocity

equipments were sufficiently warmed-up and ready, this testing began. Two series of this emissions test were performed.

After the entire set of four emissions tests was completed the sample bags were taken back to the emissions sampling bench and analyzed. Analysis was completed as soon as possible after the completion of the testing. Particulate filters used during the testing, brought weighted from ERMD in Ottawa, were sealed in petri dishes and took back to ERMD for weighting them under the same conditions as the previous one.

For engine testing, the engine was operated according to a standard transient test routine. This routine is called the US EPA Heavy Duty Engine Transient Test and is found in the Code of Federal Regulations (CFR) 40 Part 86 - Protection of Environment. Section 86: 1332-90 of this regulation specifies that the test engine first by mapped so that the torque and speed points may be defined. Mapping the engine involved operating the engine, after it was completely warmed-up, at full throttle increasing the speed at increments of $8 \mathrm{rpm} / \mathrm{s}$ between a minimum and maximum engine speed. The data from this procedure is used to create a maximum torque curve. Repeating this procedure with no engine throttle across the same speed points (motoring the engine) while measuring the amount of torque required at each speed point yielded the additional data necessary to create the transient test trace. These torque and speed values were applied to the percent speed and torque points as defined in appendix I((f)(2) of the CFR 40 Part 86 to generate the transient test cycle appropriate for the test engine. The details of the test cycle are contained in Table 2.

The test procedures prescribed for the exhaust emissions testing of the heavy-duty diesel engines are outlined in section 86.1337-90 and 86.1337-96 of the CFR 40 Part 86. The emissions testing defined in this section was performed in accordance with these standards.

Emission testing for both Colombian diesel fuels and the commercial Canadian low sulfur diesel was completed over a period of two days. On the first testing day a baseline test was performed where the engine was 
Table 2. US EPA heavy duty engine transient test summary

\begin{tabular}{|c|c|c|c|c|c|}
\hline $\begin{array}{c}\text { Test cycle } \\
\text { summary }\end{array}$ & $\begin{array}{c}\text { cycle } \\
\text { duration } \\
\text { (seconds) }\end{array}$ & $\begin{array}{c}\text { Maximum engine } \\
\text { speed } \\
\text { (\% of rated) }\end{array}$ & $\begin{array}{c}\text { Maximum torque } \\
\text { (\% of rated) }\end{array}$ & $\begin{array}{c}\text { Average engine } \\
\text { speed (\% of } \\
\text { rated) }\end{array}$ & $\begin{array}{c}\text { Average torque } \\
\text { (\% of rated) }\end{array}$ \\
\hline $\begin{array}{c}\text { Heavy duty engine } \\
\text { transient }\end{array}$ & 1199 & 111,9 & 100,0 & 41,5 & 28,3 \\
\hline
\end{tabular}

initially operated on commercial Canadian low sulfur diesel. This testing consisted of one cold and three 'hot start' emissions tests. Immediately after these emissions tests had been completed the fuel was changed over to the high sulfur Colombian diesel and the engine was operated at rated speed and power for 30 minutes. Following this the engine was stopped and the fuel filter was replaced. The engine was then left to cool down naturally. After the engine had cooled for two hours the engine was re-started and operated over one cold an three 'hot start' emissions tests. This transient test sequence for heavy duty engine can be seen in Code of Federal Regulations 40 part $86(86.1330-84)$ figure N84-10.

The emission testing procedure for the second day was identical except that the low sulfur Colombian diesel fuel was tested after the baseline commercial Canadian low sulfur diesel (Table 3).

Table 3. Engine testing schedule

\begin{tabular}{|c|c|c|}
\hline \multirow{4}{*}{$\begin{array}{l}\text { Engine } \\
\text { Emission } \\
\text { Testing } \\
\text { Day } 1\end{array}$} & \multirow{2}{*}{$\begin{array}{l}\text { Morning } \\
\text { Testing }\end{array}$} & $\begin{array}{l}\text { Commercial canadian low sulfur } \\
\text { diesel cold start and } 3 \text { hot start }\end{array}$ \\
\hline & & $\begin{array}{l}\text { Fuel exchange, fuel filter change } \\
\text { cool down }\end{array}$ \\
\hline & \multirow{2}{*}{$\begin{array}{l}\text { Afternoon } \\
\text { Testing }\end{array}$} & $\begin{array}{l}\text { Colombian high sulfur diesel } \\
\text { cold start and } 3 \text { hot start }\end{array}$ \\
\hline & & $\begin{array}{l}\text { Fuel exchange, fuel filter change } \\
\text { cool down }\end{array}$ \\
\hline \multirow{4}{*}{$\begin{array}{l}\text { Engine } \\
\text { Emission } \\
\text { Testing } \\
\text { Day } 2\end{array}$} & \multirow{2}{*}{$\begin{array}{l}\text { Morning } \\
\text { Testing }\end{array}$} & $\begin{array}{l}\text { Commercial canadian low sulfur } \\
\text { diesel cold start and } 3 \text { hot start }\end{array}$ \\
\hline & & $\begin{array}{l}\text { Fuel exchange, fuel filter change } \\
\text { cool down }\end{array}$ \\
\hline & \multirow{2}{*}{$\begin{array}{l}\text { Afternoon } \\
\text { Testing }\end{array}$} & $\begin{array}{l}\text { Colombian low sulfur diesel cold } \\
\text { start and } 3 \text { hot start }\end{array}$ \\
\hline & & $\begin{array}{l}\text { Fuel exchange, fuel filter change } \\
\text { cool down }\end{array}$ \\
\hline
\end{tabular}

\section{RESULTS}

\section{Calculation of emissions results for fleet testing}

Gaseous emissions. After the emissions tests were completed, the bag samples collected by the mobile sampling system had to be analyzed using the analyzer bench. The accuracy of these instruments was insured by calibrating them with a zero and span gas prior to testing the sample bags. While testing the sample bags, the meter readings displayed by the instrument were logged. These meter readings were then put through a "curve" for the given instrument. The curves were created in Ottawa, prior to their shipment. Using the meter reading, with the curve for the instrument, it is possible to produce a "ppm" reading for all of the given emissions.

During the operation of the mobile analysis system all of the various main flow, dilution flow, and bag flows are monitored and recorded in a computer. The knowledge of the total flows through the mobile sampling system (DOES2), combined with the calculations of the concentrations of the exhaust emissions in the bag, and a knowledge of the densities of various gases, makes it possible to calculate the actual mass of any given emission. Therefore this emission may be expressed not only as a concentration, but also as an actual mass.

While performing the emissions testing, the mobile sampling system monitored and recorded the total amount of air drawn into the engine. This information was used to calculate the total exhaust output of the engine during the testing. With this information, and our earlier calculations of the mass of the emissions from our sample of raw exhaust, we are able to calculate the total mass emissions of the engine. This is accomplished by determining the ratio of the raw 
exhaust sample that passed through the mobile emission system (DOES2) as compared to the entire raw exhaust the engine emitted.

Particulate emissions. After getting the net difference between the initial and final weight of filters, next step requires calculating the quantity of raw exhaust that was drawn through the filter by subtracting the dilution air from the total volume of the sample. After this calculation has been completed a quantity of raw exhaust is known to have contained a given mass of particulate. As was performed with the gaseous emissions calculations, the ratio between the quantity of raw exhaust that was sampled in the mobile system (DOES2) and the total exhaust output of the engine is derived. With this information, the total particulate matter produced by the engine for the entire test may be calculated.

Emission test results. The emission test results, compiled from the vehicles that exhibited results considered being the most reliable and accurate, are listed in Table 4 and plotted in Figure 5. The other vehicles were discarded for two special reasons as follows:

- The mass of particulate collected on the filters was too high and it exceeded the maximum quantity specified in the CFR 40 part 86 , for the filters with diameter of $70 \mathrm{~mm}$. Special case was the busetas with naturally aspirated engines, that practically plugged the filters before finishing the testing.

- The repeatability of the results were low, generally due to the high level of emissions produced for these engines.

When selecting the tests to be compared, only the very best emissions tests were selected. These tests were the most consistent, and considered the most reliable indicators of the relative emissions. This selection process was utilized to ensure a very high level of confidence in the analysis of the net effects of changing from $3000 \mathrm{ppm}$ sulfur diesel to $1000 \mathrm{ppm}$ sulfur diesel on the exhaust emissions from the vehicles.

Statistical analysis. A statistical study was undertaken on the compiled test data to compare the vehicles exhaust emissions from their "baseline-initial" using baseline $3000 \mathrm{ppm}$ sulfur diesel to the alternative 1000 ppm sulfur diesel configuration. This was done to clearly observe the trends in the diesel exhaust emissions that could only be attributed to the product being tested in that configuration.

The means of comparison was the 'Student t-distribution' analysis that best suits those studies looking for significance among small sample sizes, as was the case with this test program. Tables 4 shows the t-dis-

Percentage change in mass emissions when using $1000 \mathrm{ppm}$ sulfur diesel instead of $3000 \mathrm{ppm}$ sulfur diesel for all selected vehicles

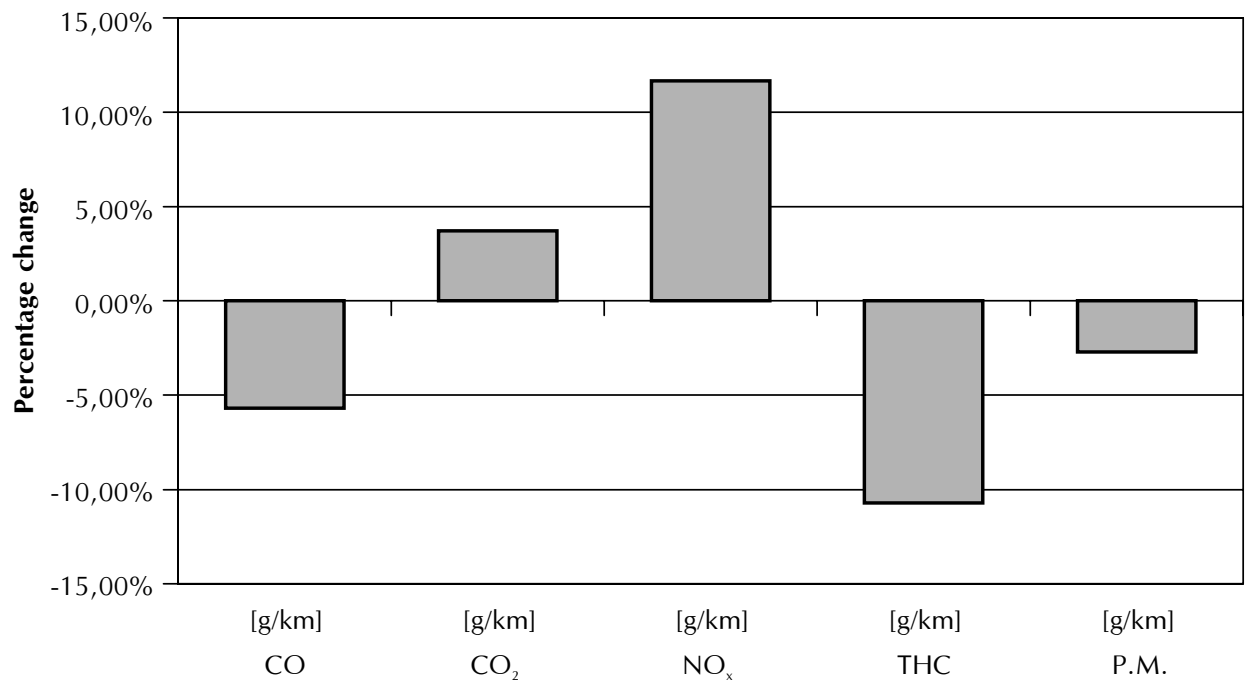

Figure 5. Comparison of mass emissions for all selected vehicles using 3000 ppm and 1000 ppm diesel fuel 
Table 4. Comparison of mass emissions for all selected vehicles using 3000 ppm and 1000 ppm diesel fuel

\begin{tabular}{|c|c|c|c|c|c|c|c|}
\hline \multicolumn{8}{|c|}{ Comparison of selected buses using 3000 ppm and 1000 ppm sulphur diesel } \\
\hline 1998 Caterpiller 3116 - Turbo & & \multicolumn{6}{|c|}{ Colombia on-road Emission Test Results } \\
\hline Test configuration & test & $\begin{array}{l}\text { Speed } \\
{[\mathrm{km} / \mathrm{hr}]}\end{array}$ & $\begin{array}{c}\mathrm{CO} \\
{[\mathrm{g} / \mathrm{km}]}\end{array}$ & $\begin{array}{c}\mathrm{CO}_{2} \\
{[\mathrm{~g} / \mathrm{km}]}\end{array}$ & $\begin{array}{c}\mathrm{NO}_{\mathrm{x}} \\
{[\mathrm{g} / \mathrm{km}]}\end{array}$ & $\begin{array}{c}\text { THC } \\
[\mathrm{g} / \mathrm{km}]]\end{array}$ & $\begin{array}{l}\text { P.M. } \\
{[\mathrm{g} / \mathrm{km}]}\end{array}$ \\
\hline Bus \# 1 with 3000 ppm diesel & hs avg & 27,8 & 2,86 & 380,28 & 3,86 & - & 0,13 \\
\hline Bus \#2 with 3000 ppm diesel & hs avg & 27,7 & 4,58 & 389,47 & 2,79 & 0,24 & 0,17 \\
\hline Bus \#3 with 3000 ppm diesel & hs avg & 28,3 & 3,18 & 421,10 & 4,20 & 0,25 & 0,23 \\
\hline Buseta \#2 with 3000 ppm diesel & hs avg & 27,4 & 19,84 & 589,23 & 2,96 & 0,75 & - \\
\hline Buseta \#4 with 3000 ppm diesel & hs avg & 28,1 & 8,22 & 460,07 & 1,78 & 0,40 & - \\
\hline Microbus \# 1 with 3000 ppm diesel & hs avg & 27,4 & 14,02 & 350,46 & 3,81 & 0,64 & 1,21 \\
\hline Microbus \#3 with 3000 ppm diesel & hs avg & 28,0 & 14,09 & 282,83 & 1,89 & 1,17 & 1,14 \\
\hline Microbus \#4 with 3000 ppm diesel & hs avg & 28,0 & 7,63 & 326,99 & 2,27 & 0,87 & 1,05 \\
\hline Selected buses with 3000 ppm diesel Avg. & 8 & 27,8 & 9,30 & 400,1 & 2,95 & 0,62 & 0,656 \\
\hline Standard deviation & & 0,339 & 6,113 & 94,018 & 0,934 & 0,345 & 0,526 \\
\hline Bus \# 1 with 1000 ppm diesel & Is avg. & 27,8 & 2,95 & 395,06 & 4,09 & - & 0,129 \\
\hline Bus \#2 with 1000 ppm diesel & Is avg. & 27,6 & 4,38 & 414,21 & 3,10 & 0,19 & 0,171 \\
\hline Bus \#3 with 1000 ppm diesel & Is avg. & 28,2 & 3,13 & 459,57 & 4,75 & 0,22 & 0,217 \\
\hline Buseta \#2 with 1000 ppm diesel & Is avg. & 28,2 & 19,44 & 603,07 & 3,71 & 0,65 & - \\
\hline Buseta \#4 with 1000 ppm diesel & Is avg. & 28,2 & 6,87 & 441,21 & 1,76 & 0,37 & - \\
\hline Microbus \# 1 with 1000 ppm diesel & Is avg. & 27,5 & 12,13 & 366,53 & 4,32 & 0,62 & 1,011 \\
\hline Microbus \#3 with 1000 ppm diesel & Is avg. & 27,8 & 14,57 & 319,38 & 2,16 & 1,11 & 1,463 \\
\hline Microbus \#4 with 1000 ppm diesel & Is avg. & 28,2 & 6,72 & 320,18 & 2,43 & 0,69 & 0,839 \\
\hline Selected buses with 1000 ppm diesel Avg. & 8 & 27,9 & 8,77 & 414,9 & 3,29 & 0,55 & 0,638 \\
\hline Standard deviation & & 0,304 & 5,994 & 91,750 & 1,096 & 0,321 & 0,550 \\
\hline$\%$ Difference & & $0,36 \%$ & $-5,70 \%$ & $3,71 \%$ & $11,67 \%$ & $-10,72 \%$ & $-2,71 \%$ \\
\hline \multicolumn{8}{|l|}{ \# degrees of freedom for statistics, $v=14$} \\
\hline Variance of comparison, $\sigma^{2}$ & & 0,104 & 36,650 & 8628,727 & 1,036 & 0,111 & 0,290 \\
\hline ' $T$ ' Distribution & & $-0,623$ & 0,175 & $-0,320$ & $-0,675$ & 0,397 & 0,066 \\
\hline \multirow{2}{*}{\multicolumn{2}{|c|}{ Statistically significant change( $95 \%$ confidence)? }} & No & No & No & No & No & No \\
\hline & & $\begin{array}{c}\text { Speed } \\
{[\mathrm{km} / \mathrm{hr}]}\end{array}$ & $\begin{array}{c}\mathrm{CO} \\
{[\mathrm{g} / \mathrm{km}]}\end{array}$ & $\begin{array}{c}\mathrm{CO}_{2} \\
{[[\mathrm{~g} / \mathrm{km}]}\end{array}$ & $\begin{array}{c}\mathrm{NO}_{\mathrm{x}} \\
{[\mathrm{g} / \mathrm{km}]}\end{array}$ & $\begin{array}{c}\text { THC } \\
{[\mathrm{g} / \mathrm{km}]}\end{array}$ & $\begin{array}{l}\text { P.M. } \\
{[\mathrm{g} / \mathrm{km}]}\end{array}$ \\
\hline
\end{tabular}


tribution calculations with the test data for the group of vehicles with the most consistent, and most reliable indicators of the relative emissions. The confidence level of statistical significance appropriate for scientific studies in a laboratory setting is considered to be the $95 \%$ boundary. Despite the fact that this project was not carried out in a controlled laboratory settings, this standard was still adopted.

After completing the statistical analysis for the selected group of vehicles, no changes in the exhaust emissions were found to be statistically significant to the $95 \%$ confidence level. There are several reasons why this was the case, even despite the existence of several strong trends in the data. The high standard deviation of the data was identified as the single most important factor that prevented the documented changes in exhaust emissions from being statistically significant. Due to the high standard deviation of the emissions results, a greater difference between the baseline and alternative fuel configurations would have been necessary to achieve a statistically significant change. Since the difference in emissions levels between the two fuels was not extreme, achieving statistical significance were not possible under these conditions.

Observations and discussion. The trends in the emissions data that were documented in all of the vehicles taken as a whole group were identical to the trends noted with the three different types of vehicles when examined in their respective groups. This repeatability and consistency in our observation allows for a high level of confidence in the results of the emission tests as they were calculated.

Looking at the effect of the alternative $1000 \mathrm{ppm}$ diesel fuel as compared to the baseline $3000 \mathrm{ppm}$ sulfur on the mass emissions of all of these vehicles, some very strong trends were found. While the trends were the same in terms of the direction of the change for the mass emissions of all vehicle groups while using the alternative 1000 ppm sulfur diesel, the relative percent change did vary depending on what type of vehicle was being tested.

In an overall overview of the data, the use of the alternative $1000 \mathrm{ppm}$ fuel resulted in reduction of 5,7\% for $\mathrm{CO}, 10,72 \%$ for $\mathrm{THC}$, and total particulate matter was reduced by $2,71 \%$. The reduction in THC and total particulate matter that were observed in the buses group were the strongest comparatively among all of the other vehicles. $\mathrm{CO}_{2}$ was seen to increase by $3,71 \%$ and $\mathrm{NO}_{x}$ was increased by $11,67 \%$.

\section{Calculation of emissions results for engine testing}

Emission testing using commercial Canadian low sulfur diesel serves as a baseline for the emissions testing. This ensured a fair comparison between the low and high sulfur Colombian diesel when they were tested. So, the first fuel to be tested on both testing days, as was shown in Table 3, was the commercial Canadian low sulfur diesel fuel. The repeatability of the brake specific emissions for the Cat 3406E engine while operating on this fuel was examined as part of the quality assurance process undertaken for this project. The emissions testing from both days using this fuel was found to be very repeatable, with no significant differences observed in the emissions between the first and second emission testing day.

In Table 5 can be seen that there were no significant differences in the measured emissions of the 1995 Cat3406E test engine while it was operating on the commercial Canadian low sulfur diesel fuel on both days. Here again, the 't-Student distribution' analysis was carried out, with a $95 \%$ confidence, for determining it. In addition, there were no significant changes in any of the recorded operating parameters for the engine as well (speed, torque and power).

This observation is an additional confirmation that all the emissions analysis equipment (i.e. exhaust gas analyzers, CFV-CVS system, engine and dynamometer control systems, etc.) were operating in a consistent and correct fashion on both testing days. It also supports the observation that the significant differences found in engine emissions while using each Colombian diesel fuel was a result of the combustion of these fuels, rather than any external variables.

Emission test results. In Table 6 can be seen the emissions results for the three hot start testing with each one of the Colombian diesel fuels (low and high sulfur), the average of the three tests and the statistical analysis of the results.

Statistical analysis. Comparing the emission testing of the low and high sulfur Colombian diesel fuel provides a summary of the main engine operating parameters of the engine during testing and the differ- 


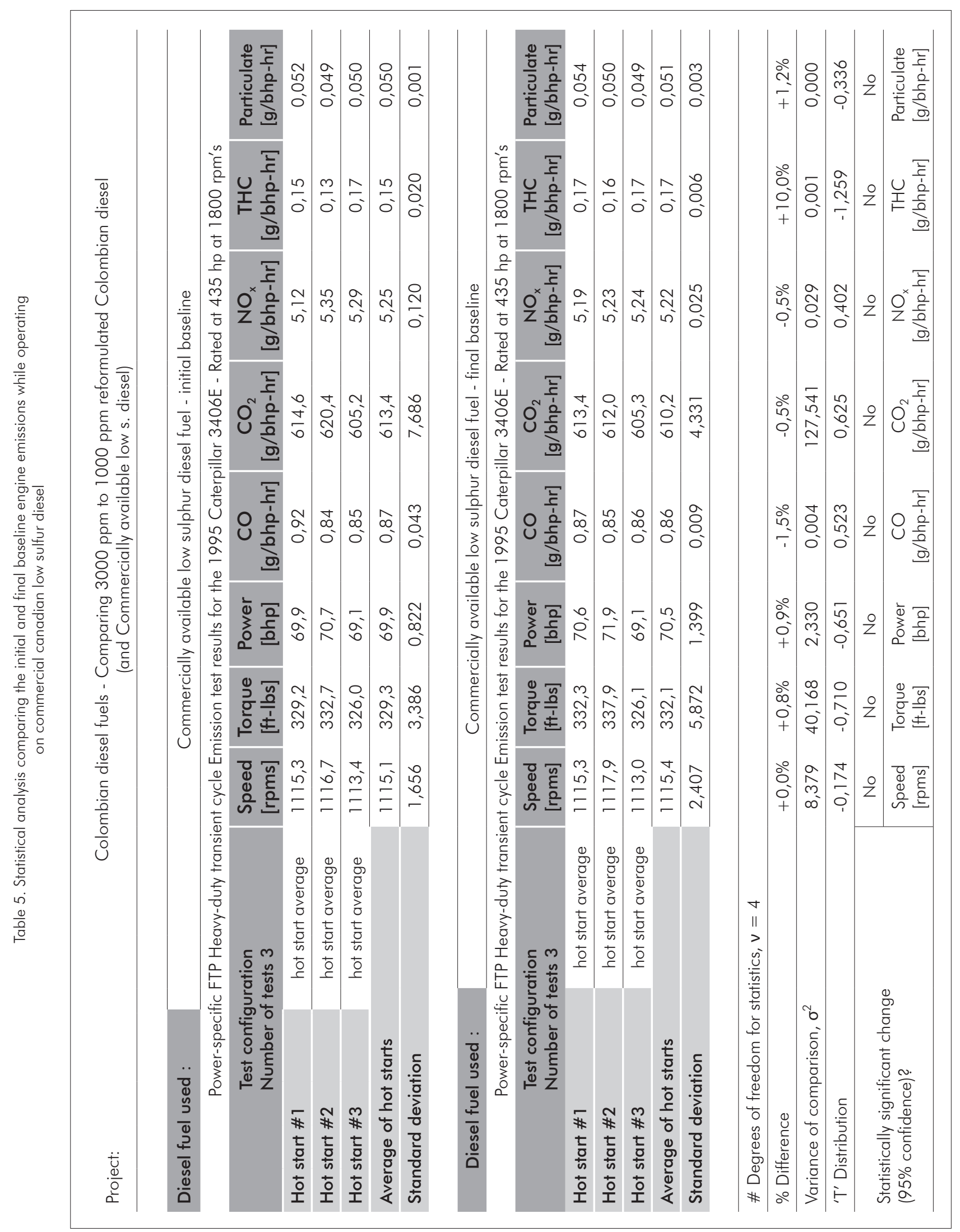




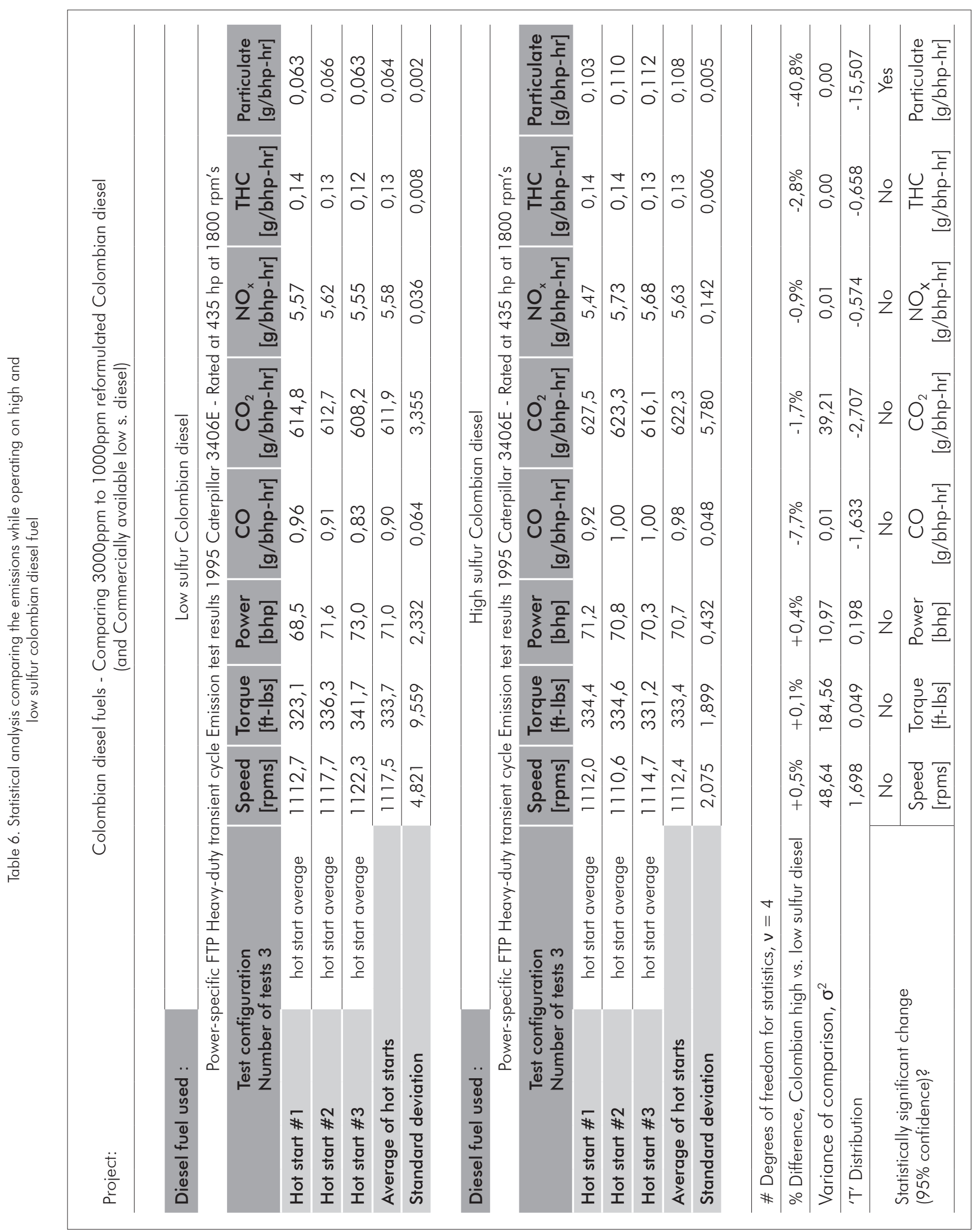


ences in the measured emissions. As shown in Table 6 , the engine was found to have operated consistently during all of the emission tests, with no statistically significant difference for engine speed, torque and power. This confirms that the engine functioned in an identical manner while operating on both the low and high sulfur Colombian diesel fuels.

Changing the test fuel from high to low sulfur Colombian diesel was found to have a reductions of 7,7\% of CO, $1,7 \%$ of $\mathrm{CO}_{2}, 0,9 \%$ of $\mathrm{NO}_{\mathrm{x}}$ and $2,8 \%$ of total hydrocarbons. These reductions were small and, assuming a 95\% confidence level, analysis determined that these reductions were not statistically significant. On the other hand, while operating on high sulfur Colombian diesel TPM emissions were found to be $0,108 \mathrm{~g} / \mathrm{bhp}-\mathrm{hr}$, under the same testing conditions, switching the diesel fuel to low sulfur Colombian diesel was found to generate TPM emissions of $0,064 \mathrm{~g} / \mathrm{bhp}-\mathrm{hr}$. This reduction was statistically significant, representing a decrease in TPM emissions of $40,8 \%$. This situation shows the real reduction obtained with the introduction of the low sulfur diesel in Bogotá, in engines with similar characteristics to the engines that transmilenio demands to be installed in its fleet of buses.

\section{CONCLUSIONS}

- The results obtained from both, fleet and engine testing, showed no statistically significant differences for THC, $\mathrm{CO}, \mathrm{CO}_{2}$ and $\mathrm{NO}_{\mathrm{x}}$ emissions when switching from high sulfur diesel (3000 ppm) to low sulfur diesel (1000 ppm). A similar trend was observed for data of Total Particulate Matter (TPM) emissions, with no statistically significant decrease in fleet testing but with a statistically significant decrease of $40,8 \%$, in the engine testing, from 0,108 $\mathrm{g} / \mathrm{bhp}-\mathrm{hr}$ to $0,064 \mathrm{~g} / \mathrm{bhp}-\mathrm{hr}$. These results were reliable and consistent and represented a good relative comparison of the exhaust emissions while using these two fuels.

- The effects of switching to $1000 \mathrm{ppm}$ sulfur diesel in the fleet of vehicles tested, resulted in a $5,7 \%$ decrease in CO emissions, $10,72 \%$ decrease in THC emissions, and 2,71\% decrease in T.P.M. Emissions of $\mathrm{CO}_{2}$ and $\mathrm{NO}_{\mathrm{x}}$ were found to increased by $3,71 \%$ and $11,67 \%$. On the other side, engine testing showed that, using reformulated low sulfur Colombian diesel fuel (1000 ppm) instead of high sulfur Colombian diesel fuel (3000 ppm) resulted in slightly reduction of Carbon Monoxide by 7,7\%, total hydrocarbons by $2,8 \%$, Carbon Dioxide by $1,7 \%$, and Oxides of Nitrogen by $0,9 \%$, although these reductions were not found to be statistically significant when analyzed by t-Student distribution.

Comparing these results with the ones obtained in 1999 by Bello, Torres, Herrera, Sarmiento (Bello et al., 2000), it can be conclude that for vehicles with engine technologies similar or superior to EURO II (that demanded for transmilenio in Bogotá), an actual reduction of TPM is obtained, while for vehicles with older technologies, although there is strong trends in reductions of CO, THC and TPM, these are not statistically confidence.

\section{BIBLIOGRAPHY}

Bello, A., Torres, J., Herrera, J. and Sarmiento, J., 2000. “The effect of diesel properties on the emissions of particulate matter". CT\&F - Ciencia, Tecnología y Futuro, 2 (1): 31-46.

Code of Federal Regulations (CFR), 1995. No.40. Part 86. Protection of Environment. Revised as of July 1, U.S. Government Printing Office, Washington.

Cowley, L. T., Stradling, J. and Doyon, J., 1993. "The Influence of Composition and Properties of Diesel Fuel on Particulate Emissions from Heavy-Duty Engines". SAE Technical Paper 932732.

Den Ouden, C. J. J., Clark, R. H., Cowley, L. T., Stradling, R. J., Lange W. W. and Maillard, C., 1994. "Fuel Quality Effects on Particulate Matter Emissions from Lightand Heavy-Duty Diesel Engines". SAE Technical Paper 942022.

Lange, W. W., 1991. "The Effects of Fuel Properties on Particulate Emissions in Heavy-Duty Engines Under Transient Operating Conditions". SAE Technical Paper 912425.

Walsh, M. P., 1993. "Global Trends in Diesel Particulate Control, 1993 Update”. SAE Technical Paper 930126. 